\title{
Positioning new pharmacotherapies for COPD
}

This article was published in the following Dove Press journal:

International Journal of COPD

24 July 2015

Number of times this article has been viewed

\author{
Igor Z Barjaktarevic' \\ Anthony F Arredondo' \\ Christopher B Cooper ${ }^{1,2}$ \\ 'Department of Medicine, ${ }^{2}$ Department \\ of Physiology, David Geffen School \\ of Medicine, University of California, \\ Los Angeles, Los Angeles, CA, USA
}

\begin{abstract}
COPD imposes considerable worldwide burden in terms of morbidity and mortality. In recognition of this, there is now extensive focus on early diagnosis, secondary prevention, and optimizing medical management of the disease. While established guidelines recognize different grades of disease severity and offer a structured basis for disease management based on symptoms and risk, it is becoming increasingly evident that COPD is a condition characterized by many phenotypes and its control in a single patient may require clinicians to have access to a broader spectrum of pharmacotherapies. This review summarizes recent developments in COPD management and compares established pharmacotherapy with new and emerging pharmacotherapies including long-acting muscarinic antagonists, long-acting $\beta-2$ sympathomimetic agonists, and fixed-dose combinations of long-acting muscarinic antagonists and long-acting $\beta$-2 sympathomimetic agonists as well as inhaled cortiocosteroids, phosphodiesterase inhibitors, and targeted anti-inflammatory drugs. We also review the available oral medications and new agents with novel mechanisms of action in early stages of development. With several new pharmacological agents intended for the management of COPD, it is our goal to familiarize potential prescribers with evidence relating to the efficacy and safety of new medications and to suggest circumstances in which these therapies could be most useful.
\end{abstract}

Keywords: COPD phenotypes, once-daily inhalers, fixed-combination inhalers, long-acting muscarinic antagonist, LAMA, long-acting $\beta$-2 sympathomimetic agonist, LABA

\section{Introduction}

COPD is characterized by chronic airway inflammation related to the inhalation of noxious particles or gases. ${ }^{1}$ The degree of inhalational injury varies and is influenced by genetic differences in individual susceptibility. ${ }^{2}$ Both factors account for remarkable heterogeneity in the clinical manifestation of COPD. Tobacco smoking accounts for at least $80 \%$ of the burden of COPD, while other contributors include occupational and environmental exposures to dust or fumes. ${ }^{3}$ COPD affects approximately $8 \%$ of the world's population, equating to approximately 160 million people, ${ }^{4,5}$ and it has been the third-leading cause of death worldwide. ${ }^{6}$ The clinical course typically evolves over several decades and early symptoms are often subtle. Disease progression in COPD is characterized by worsening airflow limitation, exacerbations occurring in varying frequency, impairment of exercise performance, and decline in health status. Management of COPD imposes a substantial economic burden, much of which is attributed to the treatment of acute exacerbations. ${ }^{7}$

Treatment of COPD can be classified as preventative, pharmacological, nonpharmacological, and surgical. The most important aspect of preventative management is avoidance of any potentially toxic exposures, especially smoking cessation, since this alone has been shown to alter the progression of the disease, at least in terms of the rate of decline in lung function. ${ }^{8}$ If we consider decline in functional capacity as an important aspect of disease progression, then it is important to acknowledge that exercise
Correspondence: Igor Z Barjaktarevic Department of Medicine, David Geffen School of Medicine, University of California, Los Angeles, 10833 Le Conte Avenue, 37-I3I CHS, Los Angeles, CA 90095, USA Email ibarjaktarevic@mednet.ucla.edu 
programs can prevent the decline of physical activity. ${ }^{9}$ Other preventative strategies include influenza and pneumococcal vaccination. ${ }^{1}$ Traditional approaches to the pharmacological treatment of COPD include short- and long-acting inhaled bronchodilator therapies, inhaled corticosteroids (ICSs), and methylxanthines. The basis of nonpharmacological treatment is recognizing the need for supplemental oxygen and pulmonary rehabilitation. ${ }^{1}$ Surgical options for severe COPD include lung volume reduction surgery, endoscopic lung volume reduction, and lung transplantation. In patients with upper lobe-predominant emphysema and poor exercise capacity, lung volume reduction surgery has shown a survival benefit. ${ }^{10}$ Endoscopic lung volume reduction is a less invasive experimental approach that is continuing to be investigated. Arguably, lung transplantation is becoming a less attractive treatment recommendation for COPD, as the survival benefit has been questioned ${ }^{11}$ and newer approaches to medical management continue to improve patient-reported outcomes.

The long-acting inhaled bronchodilators fall into two classes: long-acting muscarinic antagonists (LAMAs) and long-acting $\beta-2$ sympathomimetic agonists (LABAs). Over the past 10 years, the once-daily LAMA, tiotropium, and the twice-daily LABAs, salmeterol and formoterol, became widely prescribed for COPD. Several ICSs have also been available, some in a fixed-dose combination with a LABA. At the time of this review, several new inhaled and oral therapies have been introduced for the management of COPD and the data for their use are still limited (Table 1). Current guidelines have yet to incorporate these new therapies, suggesting the need for new treatment algorithms, such as those based on clinical staging and clinical phenotyping. ${ }^{12,13}$ This article summarizes evidence for the efficacy and safety of new therapies and suggests how they might be utilized in such algorithms.

\section{Established pharmacotherapy}

Several guidelines exist for the management of COPD, including strategies for the selection of inhaled and other pharmacotherapies. ${ }^{1,14-16}$ These guidelines are constantly evolving. Inhaled bronchodilator therapy is generally accepted as a first-line therapy for symptomatic COPD because evidence has shown improvement in dyspnea, exercise performance, reducing exacerbations, and overall health status. ${ }^{1}$ This approach differs from asthma, where ICSs are regarded as the first-line therapy for persistent symptoms because of their ability to suppress airway inflammation. ${ }^{17,18}$ Although there are many similarities in symptoms between

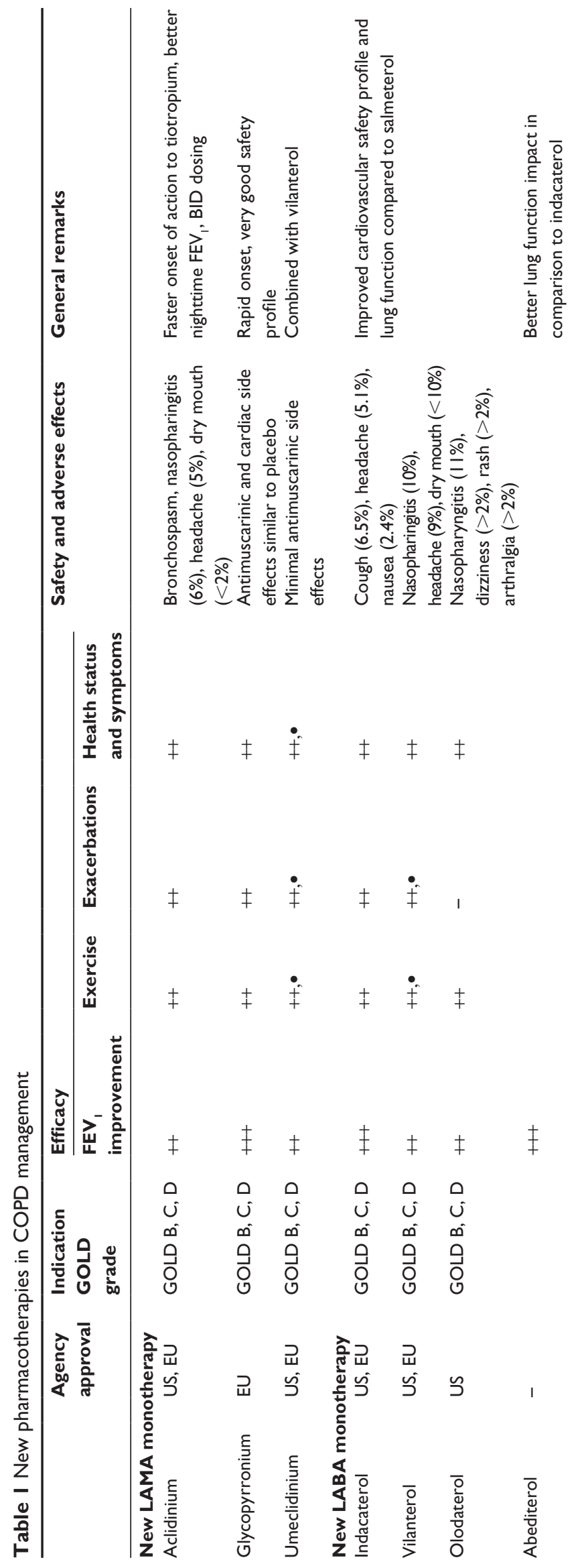



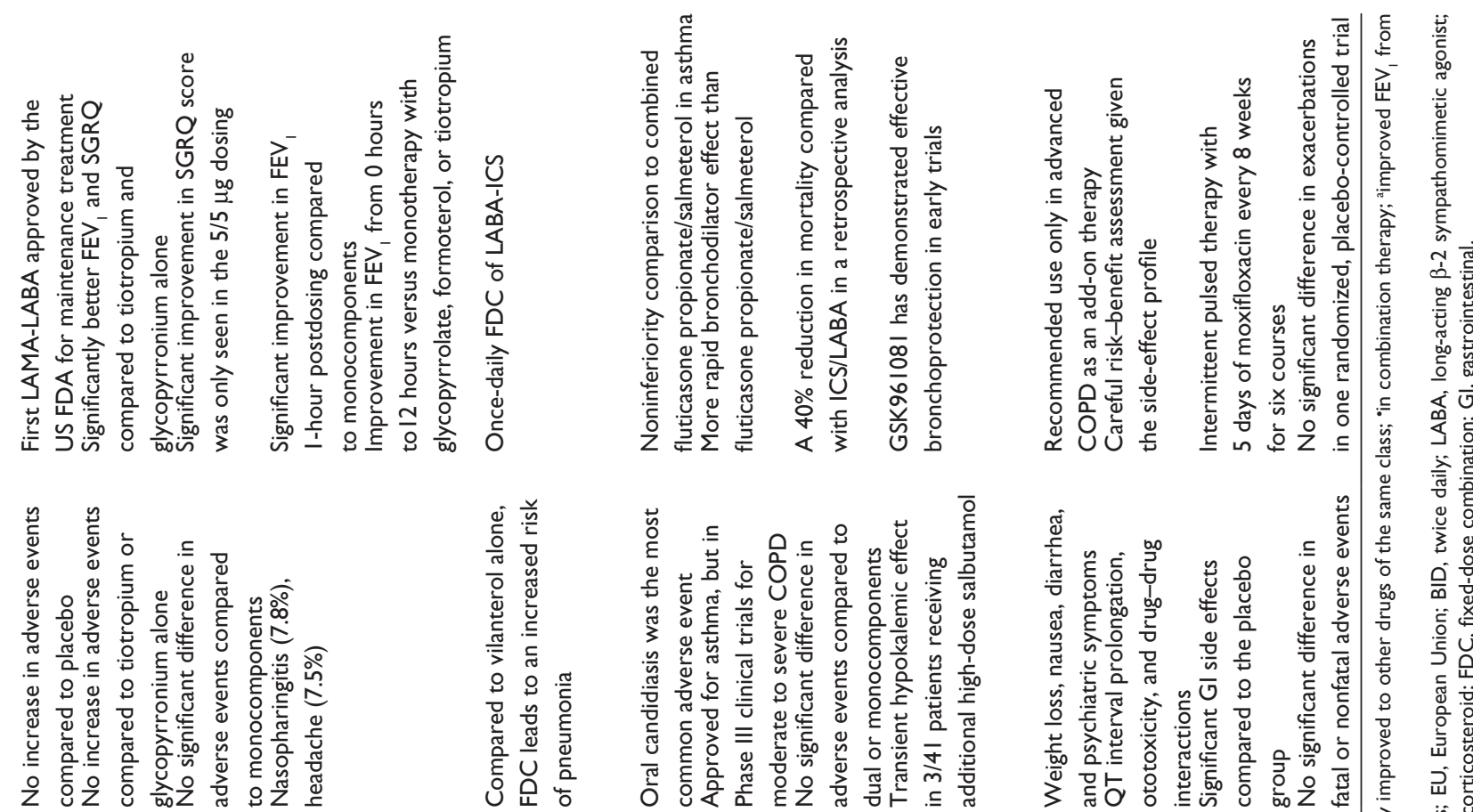
COPD and asthma, the pathophysiologic differences between toxic and allergic airway inflammation account for differences in approaches to treatment and treatment responses. Despite these differences, the management of COPD may benefit from an algorithm similar to asthma that identifies people suffering from COPD with persistent symptoms. Such patients would be candidates for the introduction of daily maintenance therapy in the form of long-acting bronchodilator therapy.

A reduction of exacerbations is also an important goal in COPD management because of their significant impact on health status, exercise performance, health care expenditure, and survival. ${ }^{19}$ Exacerbations are uncomfortable and distressing to people with COPD, and they reduce their health quality. At the same time, the impact on exercise performance reduces the possibility of an active life. Longacting bronchodilators are effective at reducing exacerbations and include LAMAs and LABAs as the mainstay of therapy. Long-acting bronchodilators also improve exercise performance ${ }^{20}$ and enhance the benefits obtained from a structured exercise rehabilitation program. ${ }^{21}$ At this stage, no treatment, apart from supplemental oxygen, has convincingly shown a reduction in COPD mortality. In a 4-year randomized clinical trial, the LAMA tiotropium showed a reduction in mortality compared to placebo at 4 years, ${ }^{22}$ and in a 3 -year randomized clinical trial, the combination of LABA-ICS compared with placebo also showed a reduction in mortality, but both failed to achieve statistical significance. ${ }^{23}$ As further data accumulate, it is postulated that bronchodilator therapy will prove to alter disease progression in COPD by reducing exacerbations portending a mortality benefit.

ICSs also reduce exacerbations in patients with severe COPD (forced expiratory volume in 1 second $\left[\mathrm{FEV}_{1}\right]<50 \%$ of predicted). ${ }^{24-26}$ Furthermore, when combined with a LABA in patients with severe COPD, ICS produces additional benefits including improvements in pulmonary function and reductions in exacerbation frequency. ${ }^{23,27}$ In patients with severe COPD, it is hypothesized that a reduction in airway inflammation and bronchial wall edema account for pulmonary function improvement. However, paradoxically, there has been a higher reported incidence of pneumonia in patients receiving ICS. ${ }^{28,29}$ The reduction in exacerbations, and yet the increased risk of pneumonia, appears to be contradictory at face value. One explanation is that, despite the reduced airway inflammation and improved lung function, the effects of ICSs on local immune response mechanisms may allow for invasive bacterial infection.

\section{New LAMA monotherapy Aclidinium}

Long-acting anticholinergic agents are considered the most effective class of bronchodilators for COPD. ${ }^{1,14}$ While tiotropium was launched in 2004 and was the only available longacting anticholinergic bronchodilator marketed for COPD until recently, there are now other LAMAs in various stages of trial development or regulatory approval. ${ }^{30-33}$ Aclidinium bromide (Tudorza) is a LAMA that was simultaneously approved in the United States and Europe in 2012 for the maintenance treatment of COPD. The drug is formulated as a dry powder and delivered via a novel multidose inhaler (Pressair in the US; Genuair ${ }^{\circledR}$ in the European Union [EU]) at a US Food and Drug Administration (FDA)-approved dose of $400 \mu \mathrm{g}$ twice daily. Twice-daily aclidinium significantly improved pulmonary function $\left(\mathrm{FEV}_{1}\right)$, dyspnea, and health status, and it was well tolerated in patients with COPD. ${ }^{34,35}$ In one study assessing 24-hour pulmonary function in people suffering from COPD, aclidinium $400 \mu \mathrm{g}$ twice daily provided clinically meaningful improvements compared to placebo with an effect size compared to tiotropium $18 \mu \mathrm{g}$ once daily. ${ }^{36}$ Compared to placebo, significant changes from baseline $\mathrm{FEV}_{1}$ were detected 15 minutes postdose of aclidinium, with a peak effect at 2 hours at a time when aclidinium was no longer detectable in plasma. ${ }^{37}$ This interesting feature of aclidinium probably reflects rapid plasma hydrolysis, which might account for reduced systemic exposure and a lower reported incidence of anticholinergic side effects. In registration studies, the incidence of anticholinergic adverse events was low, and similar to placebo. ${ }^{34-36,38-41}$ Furthermore, aclidinium is reported with minimal cardiovascular risks. ${ }^{34,36,42}$ Another potential advantage over tiotropium is that aclidinium reaches therapeutic levels within 2 days, which is compared to more than 7 days for tiotropium. An obvious disadvantage is the need for twice-daily dosing, but as a result of this, aclidinium is reported to give higher nighttime $\mathrm{FEV}_{1}$ values and lower overnight COPD symptom scores. ${ }^{36}$

\section{Glycopyrronium}

Glycopyrronium bromide is a synthetic quaternary ammonium compound with a nonselective affinity for all five muscarinic receptor subtypes. Its prior use as a systemic anticholinergic medication has included control of oral secretions, control of urinary incontinence, and vagal blockade during cardiac surgery. Although the systemic formulation was never approved for the treatment of COPD, an inhaled formulation has now been developed for once-daily COPD treatment. ${ }^{43,44}$ Its relative kinetic selectivity for the M3 versus 
M2 receptors facilitates airway smooth muscle relaxation. In terms of its bronchodilator effects, glycopyrronium has demonstrated superiority compared to placebo. ${ }^{45,46} \mathrm{In}$ comparison with tiotropium, it showed a faster onset of action ${ }^{47}$ and a significantly higher $\mathrm{FEV}_{1}{ }^{45}{ }^{4}$ Glycopyrronium significantly reduced the risk of COPD exacerbations by $31 \%$ compared with placebo. Treatment with glycopyrronium bromide also improved exercise endurance time and inspiratory capacity in patients with moderate to severe COPD, suggesting a beneficial effect on dynamic hyperinflation, which is compared to other LAMAs such as tiotropium and aclidinium. ${ }^{47}$ Glycopyrronium has a higher incidence of dry mouth, but a favorable safety profile with an overall incidence of adverse events similar to placebo. ${ }^{47}$ Glycopyrronium $\left(\right.$ Seebri $^{\circledR}$ ) was approved in the EU in 2012 and is delivered via a novel dry-powder inhaler (Breezhaler $\left.{ }^{\circledR}\right)$.

\section{Umeclidinium}

Umeclidinium bromide is a LAMA that has been developed and approved for both monotherapy and combination use in the maintenance management of COPD. Clinically significant and important improvements in lung function were observed over a 24-hour period, indicating that umeclidinium would be an effective COPD medication and suitable for once-daily dosing. ${ }^{48}$ In a randomized, placebo-controlled trial, umeclidinium at doses of $62.5 \mu \mathrm{g}$ and $125 \mu \mathrm{g}$ over 12 weeks improved pulmonary function (weighted mean $\mathrm{FEV}_{1}$ ), breathlessness, and health status..$^{49}$ Umeclidinium was well tolerated over a wide range of doses in patients with COPD with no clinically significant adverse effects. ${ }^{49,50}$ Umeclidinium (Incruse ${ }^{\mathrm{TM}}$ ) was approved by the US FDA in April 2014 as a monotherapy with a dose of $62.5 \mu \mathrm{g}$ once daily. It is formulated as a dry powder and is delivered via a novel inhaler $\left(\right.$ Ellipta $\left.^{\circledR}\right)$.

\section{New LABA monotherapy Indacaterol}

Indacaterol is a LABA with stronger affinity toward $\beta-2$ adrenergic receptors when compared to salmeterol. In addition to once-daily dosing, other advantages include longer duration, faster onset of action, and an improved cardiovascular safety profile when compared to salmeterol. ${ }^{51}$ Indacaterol was shown to be superior in bronchodilator efficacy and clinical outcomes when compared with the twice-daily LABAs. ${ }^{52-55}$ In a noninferiority study directly comparing indacaterol to tiotropium for 12 weeks, ${ }^{56}$ both drugs showed similar efficacy in terms of increased trough $\mathrm{FEV}_{1}$. Indacaterol also had a significantly greater bronchodilator effect than tiotropium within 1 hour from the first dose. Indacaterol treatment is accompanied by significant reductions in dyspnea and as-needed albuterol use. Health status generally improved with decreases from baseline St George's Respiratory Questionnaire (SGRQ) score greater than four units. ${ }^{57}$ Indacaterol also has been shown to reduce COPD exacerbations ${ }^{57}$ and improve exercise endurance time as compared to placebo. ${ }^{58}$ Compared to tiotropium monotherapy, adding indacaterol with tiotropium improved the bronchodilator effect and lung deflation. ${ }^{52}$

The safety of indacaterol has been thoroughly studied; $52,53,56,59,60$ its major side effects include tremor and tachycardia, but it appears to have low arrhythmogenic potential. ${ }^{51,59,61}$ Indacaterol has been approved in more than 50 countries for the maintenance treatment of COPD. In 2009 , indacaterol $\left(\right.$ Onbrez $\left.^{\circledR}\right)$ was approved in the EU at doses of $150 \mu \mathrm{g}$ and $300 \mu \mathrm{g}$ inhaled once daily delivered via a novel dry-powder inhaler $\left(\right.$ Breezhaler $\left.^{\circledR}\right)$. In the US, the US FDA had issues with indacaterol dosing, ${ }^{62}$ but it approved indacaterol (Arcapta ${ }^{\mathrm{TM}}$ ) in July 2011 at a dose of $75 \mu \mathrm{g}$ once daily, delivered by a dry-powder inhaler (Neohaler ${ }^{\mathrm{TM}}$ ).

\section{Vilanterol}

Vilanterol trifenatate is a novel LABA anticipated for inhaled once-daily administration in combination with an ICS fluticasone furoate $\left(\right.$ Relvar $^{\circledR}$ Ellipta $^{\circledR}$, Breo $^{\circledR}$ Ellipta $^{\circledR}$, Revinity ${ }^{\circledR}$ Ellipta $^{\circledR}$ ) or in combination with the LAMA umeclidinium $\left(\right.$ Anoro $^{\circledR}$ Ellipta $\left.^{\circledR}\right) \cdot{ }^{63-65}$ The pharmacokinetics of vilanterol is consistent with a dose-dependent, rapid-onset, 24-hour lasting bronchodilator in patients with COPD. It is a highly selective LABA with affinity toward $\beta-2$ adrenoreceptors similar to salmeterol, but with a significantly faster onset of action. ${ }^{66}$ The tolerability profile is similar to placebo ${ }^{63,67} \mathrm{~A}$ recently published randomized control 12-week study compared the cardiac safety of this combination to tiotropium alone.$^{68}$ The results showed no difference in aortic pulse wave velocity, a predictor of cardiovascular events and mortality.

Combination therapy with both fluticasone and umeclidinium was shown to improve lung function and reduce exacerbations when compared to monotherapy. ${ }^{69-71}$ Vilanterol has received approval by the US FDA for the maintenance treatment of COPD in the form of a fixed-combination therapy only. ${ }^{72}$

\section{Olodaterol}

Olodaterol is another novel LABA with dose-dependent bronchodilator effects lasting up to 24 hours. ${ }^{67,73,74}$ Furthermore, it protects against methacholine-induced bronchoconstriction 
in patients with intermittent asthma for up to 32 hours after administration of a single dose. ${ }^{67,75}$ In a 48-week study of moderate to very severe $\mathrm{COPD},{ }^{76}$ olodaterol once daily was compared to both formoterol twice daily and placebo. Olodaterol and formoterol improved $\mathrm{FEV}_{1}$ when compared to placebo, but olodaterol also showed significant improvements in reported symptoms. ${ }^{76}$ Along with tiotropium, olodaterol has been investigated as a potential agent that counters the detrimental effect of the Th-17 immune response in the development of COPD. ${ }^{77}$ Adverse effects reported with olodaterol were comparable with placebo in two clinical trials. ${ }^{67,78}$ Olodaterol (Striverdi ${ }^{\circledR}$ ) was initially designed for use in combination with tiotropium to provide added benefit for patients with COPD. It is currently approved as a monotherapy in over 30 countries and it was approved by the US FDA in August 2014 for the maintenance treatment of COPD at a dose of $5 \mu \mathrm{g}$ once daily, delivered by a softmist inhaler (Respimat ${ }^{\circledR}$ ).

\section{Abediterol}

Early clinical trials indicate that abediterol may be a potent, rapid, and long-acting bronchodilator. ${ }^{79}$ Abediterol elicits bronchodilation 5 minutes after dosing, which is faster and longer lasting than salmeterol $50 \mu \mathrm{g}$ twice daily. ${ }^{67,80}$ The high level of $\beta$-2 adrenoreceptor subtype selectivity may account for its comparable cardiovascular safety and tolerability profile when compared to placebo. ${ }^{63,81,82}$

\section{New LAMA-LABA combination therapies Background}

Combination therapy involving two long-acting bronchodilators with differing mechanisms of action has been recommended in patients whose COPD is not well controlled with one drug alone. ${ }^{1,12}$ LAMA and LABA combinations show synergistic bronchodilator effects at doses used for monotherapy. ${ }^{83,84}$ In addition, fixed-dose combination LAMA-LABA regimens may be more convenient and lead toward better adherence by patients. ${ }^{85}$

\section{Umeclidinium and vilanterol}

Umeclidinium/vilanterol (Anoro $^{\circledR}$ Ellipta $^{\circledR}$ ) is a once-daily LAMA-LABA combination drug that was shown to improve lung function compared with vilanterol or tiotropium alone in patients with COPD. ${ }^{70}$ In recent randomized controlled trials, its use has led to statistically significant improvements in $\mathrm{FEV}_{1}$, health status, and dyspnea scores during the 24-week period when compared to placebo and to umeclidinium and vilanterol monotherapies. ${ }^{69,85}$ This combination was proven to be safe and well tolerated, ${ }^{86-88}$ and it has become the first fixed-dose combination LAMA-LABA product approved by the US FDA for the maintenance treatment of COPD.

\section{Glycopyrronium and indacaterol}

In a recently published trial, ${ }^{89}$ the glycopyrronium/indacaterol combination was compared to its individual components (glycopyrronium and indacaterol) and tiotropium for the treatment of moderate to severe COPD. The results revealed better efficacy with the inhaled combination therapy when compared with glycopyrronium or tiotropium alone. Analyzing the efficacy compared to indacaterol, two studies ${ }^{90,91}$ grouped together, including 1,399 patients with moderate to severe COPD, revealed significantly improved $\mathrm{FEV}_{1}$ in the glycopyrronium/indacaterol group compared to indacaterol alone. The overall incidence of adverse events was similar across both treatment groups. ${ }^{92}$

Glycopyrronium/indacaterol (Ultibro ${ }^{\circledR}$ Breezhaler ${ }^{\circledR}$ ) was the first-in-class once-daily dual bronchodilator approved in Europe in 2013 for use by patients suffering from COPD.

\section{Tiotropium and olodaterol}

The combination of tiotropium and olodaterol is under development as a soft-mist inhaler. Results from a recent randomized, double-blind, parallel-group, multicenter, Phase III trial comparing the fixed-dose combination inhaler to its monocomponents revealed significant improvements in $\mathrm{FEV}_{1}$ and SGRQ score. ${ }^{74}$ Patients enrolled in the study had moderate to very severe COPD and were followed for 1 year. The significant improvement in SGRQ score was only seen with the tiotropium/olodaterol dosing of $5 / 5 \mu \mathrm{g}$ daily.

\section{Aclidinium and formoterol}

Aclidinium bromide/formoterol fumarate (Duaklir Pressair) is an investigational fixed-dose combination of two approved long-acting bronchodilators given twice daily. A Phase III clinical trial ${ }^{93}$ combining formoterol fumarate and aclidinium bromide resulted in significantly improved $\mathrm{FEV}_{1}$ through a 24-week period. There were no significant differences in health status, as reflected by health-related quality of life scores and rate of exacerbations between the fixed-dose combination, aclidinium bromide, formoterol fumarate, and placebo.

\section{Glycopyrrolate and formoterol}

The formoterol/glycopyrrolate (PT003) fixed-dose combination delivered via a pressurized hydrofluoroalkane 
is currently in Phase III trials for use in moderate to very severe COPD in the US and Europe. ${ }^{94-99}$ Recent studies reported improvements in $\mathrm{FEV}_{1}$ area under the curve from 0 hours to 12 hours versus monotherapy with glycopyrrolate, formoterol, or tiotropium, and in inspiratory capacity versus tiotropium monotherapy. ${ }^{83,100,101}$

\section{New LABA-ICS combination therapies Background}

Evidence suggests that LABA and ICS have synergistic effects in the airways of people living with COPD. ICS can potentiate LABA effects by preventing the reduction of cell surfaceexpressed $\beta$-receptors that occurs with severe airway inflammation. Concurrently, LABAs may have steroid-sparing, anti-inflammatory, and antiproliferative properties. ${ }^{102}$ It has been postulated that the simultaneous inhalation of both drugs via a single device in a single breath may maximize the drug codeposition and facilitate greater interaction between the ICS and the LABA. ${ }^{103}$ In a recent meta-analysis by the Cochrane network, ${ }^{104}$ the ICS/LABA combination demonstrated the most significant improvement in both the SGRQ and $\mathrm{FEV}_{1}$ compared to placebo. In addition, combination therapy showed improvement over LAMA, LABA, and ICS therapy alone. ${ }^{104}$ Recently, a published review of comparative safety in inhaled COPD regimens found that ICS/LABA had the lowest risk of mortality when compared with placebo, tiotropium, or LABA alone. ${ }^{105}$ There are now new LABA-ICS fixed-dose combinations to add to the previously available twice-daily combinations, which have included fluticasone/ salmeterol (Advair), budesonide/formoterol (Symbicort), and mometasone/formoterol (Dulera).

\section{Vilanterol and fluticasone}

Vilanterol/fluticasone furoate (Relvar ${ }^{\circledR}$, Breo $^{\circledR}$, Revinty ${ }^{\circledR}$ ) is a fixed-dose combination of ICS and LABA for oncedaily administration via a dry-powder inhaler (Ellipta $\left.{ }^{\circledR}\right)$, and this has recently been approved by the US FDA for patients suffering from COPD. ${ }^{106}$ In comparison to twicedaily fluticasone propionate/salmeterol, fluticasone furoate/ vilanterol once daily has shown trends for improved $\mathrm{FEV}_{1}$, but without clinical significance in multiple 12-week trials. ${ }^{107}$ Compared to vilanterol alone, the combination regimen showed significantly fewer moderate to severe COPD exacerbations. ${ }^{71}$ Serious adverse effects are similar to the fluticasone propionate/salmeterol inhaler. ${ }^{107}$ In comparison to vilanterol only, fluticasone furoate/vilanterol led to an increased risk of pneumonia, fractures, and mortality. ${ }^{71}$
A key advantage is not evident through its efficacy, but in its once-daily dosing, which offers greater convenience to patients and ideally improves compliance.

\section{Indacaterol and mometasone}

The combination of indacaterol acetate and mometasone furoate (QMF149; Novartis International AG, Basel, Switzerland) is also in the late stages of development. ${ }^{108}$ Its safety, tolerability profile, and effect on lung function compared to placebo in airway diseases have shown promising results. $^{74,109,110}$

\section{Formoterol and ciclesonide}

The combination of formoterol and ciclesonide (Alvesco Combo) has been investigated in moderate asthma patients. In a Phase II trial, ${ }^{111}$ formoterol/ciclesonide was found to be noninferior to fluticasone/salmeterol in terms of both efficacy and tolerability. Studies investigating its use in COPD are still lacking.

\section{Formoterol and fluticasone}

The combination of fluticasone propionate/formoterol (Flutiform $^{\circledR}$, Abriff $^{\circledR}$, or Iffeza ${ }^{\circledR}$ ) in a single inhaler provides potent anti-inflammatory activity of fluticasone propionate and rapid onset of action of the $\beta 2$-agonist formoterol. ${ }^{112}$ It has been marketed for use in asthma in Europe and Japan, and it has been in Phase III trials for its use in moderate to severe COPD. The efficacy of fluticasone/formoterol in patients with asthma was shown to be noninferior to that of fluticasone/ salmeterol or budesonide/formoterol with a tolerability profile generally similar to that of these two combinations. ${ }^{113}$

\section{Triple LABA-LAMA-ICS therapy}

Triple therapy consisting of LABA, LAMA, and ICS has been investigated showing benefits in comparison to LABA-ICS or LAMA alone. ${ }^{14-122}$ Tiotropium added to the salmeterol/ fluticasone combination did not lead to fewer exacerbations in comparison to the three component parts alone, but it did improve lung function and disease-specific quality of life compared to tiotropium monotherapy. ${ }^{122}$ Triple therapy was associated with a $40 \%$ reduction in mortality compared with ICS/LABA in a retrospective analysis among veterans with COPD. ${ }^{117}$ Based on the Global Initiative for Chronic Obstructive Lung Disease (GOLD) update in 2013, patients classified as group D should be prescribed with ICS combined with a LABA or LAMA, "with some evidence for triple therapy". ${ }^{1}$ Currently, there are several inhalers containing LAMA-LABA-ICS combinations undergoing early phase 
clinical trials, including glycopyrronium/formoterol fumarate/budesonide inhalation aerosol (BGF MDI, PT010), umeclidinium/vilanterol/fluticasone inhaler, and tiotropium/ formoterol furoate/ciclesonide inhaler (Triohale).

\section{Dual muscarinic antagonist- $\beta 2$ - agonists (MABAs)}

MABAs, which can deliver a fixed ratio of muscarinic antagonist and $\beta_{2}$-agonist to the whole lung with a single pharmacokinetic profile, comprise an attractive idea that could further facilitate the application of "triple therapy". ${ }^{83}$ One of furthest developed MABAs, GSK961081, has demonstrated effective bronchoprotection in vivo as proof of concept, and it is still in early clinical trials. ${ }^{123}$

\section{Oral medications}

\section{Roflumilast}

Oral phosphodiesterase (PDE) inhibitors have been shown to relax smooth muscle, suppress the activation of inflammatory cells, and modulate the activity of pulmonary nerves. ${ }^{124}$ Xanthines such as theophylline are nonselective PDE inhibitors, and they were among the first agents used in the treatment of COPD. Due to a very narrow therapeutic window and their severe adverse effects, their popularity decreased over past decades as new and safer agents became available. In search for more specific PDE inhibitors, the development of PDE3 and/or PDE4 inhibitors, as well as the enzymes responsible for metabolizing cyclic adenosine monophosphate in the airway and pulmonary smooth muscle, showed promise in the treatment of respiratory diseases like asthma and COPD. ${ }^{125,126}$ Cilomilast is a second-generation PDE4 inhibitor that had initially shown improvements in efficacy endpoints and provided evidence for an anti-inflammatory mechanism of action, but Phase III studies failed to definitively confirm these findings, which led to the termination of the development of cilomilast. ${ }^{127}$ Roflumilast (Daliresp ${ }^{\circledR}$ ) is a newly approved selective PDE4 inhibitor for the treatment of severe COPD associated with chronic bronchitis and frequent exacerbations. ${ }^{128}$ It is an oral once-daily drug, currently available in $500 \mu \mathrm{g}$ tablets. Roflumilast improved $\mathrm{FEV}_{1}$ to a degree compared to that of ICSs in clinical trials, ${ }^{129-131}$ but its effects on the rates of exacerbation and quality of life measures have not been as consistent. ${ }^{128}$ The safety profile of roflumilast, while improved compared to nonspecific PDE inhibitors, still leads to its recommended use only in advanced COPD as an add-on therapy. Its side effects are generally tolerable, but significant weight loss, diarrhea, and psychiatric symptoms remain reasons for the cautious use of this medication. ${ }^{128,132,133}$

\section{Azithromycin}

Multiple studies have confirmed the correlation between lower airway bacterial colonization and acute exacerbations of COPD. ${ }^{134-136}$ Furthermore, a classic study showed improved outcomes after antibiotic treatment in patients with two of the three classic symptoms (increased dyspnea, increased sputum volume, and sputum purulence). ${ }^{137}$ A patient who continues to have frequent acute exacerbations despite guideline-based treatment is a potential candidate for prophylactic use of azithromycin. In addition to its antimicrobial efficacy, azithromycin may have anti-inflammatory and immune-modulating effects. ${ }^{138}$ Several prospective studies focused on a long-term use of azithromycin (azithromycin $500 \mathrm{mg}$ versus placebo three times a week for 12 months, and azithromycin 250 $\mathrm{mg}$ daily versus placebo). These studies revealed significant reductions in acute exacerbations, hospitalizations, and length of hospital stay in patients with severe COPD. ${ }^{139-142}$ In a large, placebo-controlled, randomized trial among selected patients with COPD, ${ }^{143}$ azithromycin $250 \mathrm{mg}$ taken daily for 1 year, when added to usual treatment, decreased the frequency of exacerbations by $27 \%$ and improved quality of life. Of particular importance for patients with frequent exacerbations (three or more exacerbations per year), maintenance treatment with azithromycin significantly decreased the exacerbation rate compared with placebo. ${ }^{141}$ A recently published study evaluated daily azithromycin use for the prevention of acute exacerbations of COPD. ${ }^{144}$ This study showed prolonged time to first exacerbation in older patients ( $>65$ years) and those with GOLD spirometric stages 3 and 4 . However, there was no effect on exacerbations in active smokers.

One of the shortcomings of azitrhomycin therapy is that, although it is less likely to become colonized with respiratory pathogens, persons suffering from COPD are more likely to become colonized with macrolide-resistant organisms. ${ }^{143}$ Other serious concerns include three major categories of adverse effects that may be anticipated with the year-long use of azithromycin. These include cardiac toxicity and QT interval prolongation, ${ }^{145}$ ototoxicity, ${ }^{143}$ and drug-drug interactions from CYP3A4 iso-enzyme inhibition. ${ }^{138}$ Collectively, these concerns are enough to promote controversy regarding treatment recommendations. ${ }^{146-153}$ The GOLD report ${ }^{1}$ even states that "a recent trial of daily azithromycin showed efficacy on exacerbation end points; however, treatment is not recommended because of an unfavorable balance between benefits and side effects".

\section{Moxifloxacin}

In a randomized controlled trial, pulsed moxifloxacin $400 \mathrm{mg}$ taken orally once daily for 5 days, repeated every 8 weeks for 48 weeks, significantly reduced COPD exacerbations by 
$25 \%(P=0.046)$. A greater reduction in COPD exacerbations (a $45 \%$ reduction) was seen in patients with purulent or mucopurulent sputum at baseline. ${ }^{154}$ This study further illustrates the efficacy of antimicrobial therapy in a selected population of patients with COPD.

\section{Simvastatin}

Another randomized controlled trial investigated the effects of statin therapy on the frequency of COPD exacerbations. ${ }^{155}$ A total of 885 participants with COPD were involved in this study. Simvastatin $40 \mathrm{mg}$ or placebo was taken orally once daily, for between 12 months and 36 months. However, the rate of exacerbations was not different between the two groups.

\section{New therapy in development}

Although therapeutic advances in the treatment of COPD and emphysema are promising, our understanding of the pathophysiology is incomplete. Given the complexity of COPD, there are multiple potential targets for the treatment of this disease and for prevention of its progression.

Novel inhaled dual PDE3 and PDE4 inhibitors, such as RPL554 and the PDE4 inhibitor CHF6001, are being investigated for their potential bronchodilator and antiinflammatory effects in asthma and COPD. In multiple functional assays, CHF6001 was shown to be more potent than the previously described PDE4 inhibitors, such as roflumilast (UK-500,001) and cilomilast. ${ }^{156}$ In four exploratory studies, inhaled RPL554 was proven to be an effective and well-tolerated bronchodilator and anti-inflammatory drug. ${ }^{157}$ Several early clinical studies of short duration and small sample sizes showed promising safety profiles and bronchodilator response of these compounds with comparable efficacy to salbutamol. ${ }^{157,158}$

A novel macrolide/fluoroketolide, solithromycin (CEM101), which is currently being investigated in the treatment of community-acquired pneumonia, has shown better antiinflammatory profiles compared with the currently available macrolides, and it may be a promising anti-inflammatory and antimicrobial drug for the treatment of COPD in the future. ${ }^{159}$

$\mathrm{N}$-acetylcysteine (NAC) is one of the most widely used and tested antioxidants. This drug has been shown to reduce bronchial hypersecretion and has been used as a mucolytic for many years. ${ }^{160-163}$ Only recently have studies addressed its effects more scientifically; it has reportedly slowed the decline in $\mathrm{FEV}_{1}$ and led to a reduction in the number of COPD exacerbations. ${ }^{164-167}$

Antagonists of the human CXCR2 receptors may affect neutrophil trafficking, and they have been investigated in
COPD. One of the CXCR2 antagonists, MK-7123, showed improved $\mathrm{FEV}_{1}$ in comparison to placebo in patients with COPD, and it has also been investigated in Phase II clinical trials. ${ }^{168}$

Other potential therapeutic targets include the regulation of signaling pathways - for example, by p38 mitogenactivated protein kinase (p38 MAPK). p38 MAPK inhibitors have shown favorable anti-inflammatory properties and have the potential to reverse corticosteroid insensitivity in COPD. ${ }^{169}$ Early clinical trials of an oral p38 MAPK inhibitor (PH-797804) showed favorable tolerability, improved $\mathrm{FEV}_{1}$, and improved baseline dyspnea index compared with placebo. ${ }^{169,170}$ Nevertheless, Phase II trials of this agent have recently been discontinued. ${ }^{171}$ Another potent oral p38 $\alpha / \beta$ MAPK inhibitor, losmapimod (GW856553X), is in a Phase II human clinical trial for the treatment of COPD. ${ }^{172}$ Also, acumapimod is an orally delivered p38 MAPK inhibitor that remains in active development. ${ }^{173}$ Inhaled delivery of p38 MAPK inhibitors may enhance $p 38$ inhibition in the lung while reducing unwanted systemic effects. The efficacy and safety of two inhaled p38 MAPK inhibitors, RV-568 and PF-03715455, are currently being evaluated in clinical trials. ${ }^{173}$

Based on the hypothesis that inflammation in COPD is a consequence of a protease and antiprotease imbalance, antagonizing matrix metalloproteinases (MMP) with selective MMP inhibitors offers a potential solution. ${ }^{174} \mathrm{~A}$ dual MMP9-MMP12 inhibitor (AZ11557272) was shown to prevent emphysema, small airway fibrosis, and inflammation in guinea pigs that were exposed to cigarette smoke over a 6-month period, ${ }^{175}$ but its clinical development has recently been stopped. Another potent and reversible inhibitor of human MMP9 and MMP12 (AZD1236) administered orally has failed biomarker endpoints for COPD, despite initial promising results, so its further development has also been aborted.

Emerging anticytokine therapies require careful selection of patients with COPD. ${ }^{176}$ Benralizumab and mepolizumab are humanized monoclonal antibodies directed at the alpha subunit of the interleukin (IL)-5 receptor (IL-5R $\alpha$ ). Both drugs are currently in Phase III development for both COPD and severe asthma. ${ }^{177-188}$ Benralizumab was shown to reduce COPD exacerbations and improve other symptoms of COPD in certain patient groups. ${ }^{189}$ Patients with higher baseline levels of blood eosinophils who were treated with benralizumab showed greater improvements in COPD symptoms, including exacerbation rate, lung function, and disease-specific health status, as measured by the SGRQ-COPD (SGRQ-C) when compared with placebo-treated subjects. ${ }^{189}$

Antihuman IL-17R antibodies (such as ixekizumab, brodalumab, and ustekinumab) are currently available for 
clinical studies in COPD, having recently been reported in a study of patients with asthma. ${ }^{190}$

The phosphoinositide 3-kinases (PI3K) are a family of proteins that control a wide variety of intracellular signaling pathways and may be attractive in the management of COPD since they may restore steroid effectiveness under conditions of oxidative stress. ${ }^{191} \mathrm{PI} 3 \mathrm{~K} \delta$ inhibition with agents such as GSK2269557 may also prevent recruitment of inflammatory cells, including T-lymphocytes and neutrophils as well as the release of proinflammatory mediators such as cytokines, chemokines, reactive oxygen species, and proteolytic enzymes. ${ }^{65,191}$

Soluble epoxide hydrolase inhibitors may also play a pharmacological role in the future treatment of COPD. Treatment with soluble epoxide hydrolase, such as t-TUCB which is in its early stages of development - may increase fatty acid epoxides and indirectly reduce the production of Th1 cytokines and proinflammatory lipid mediators, while minimizing airway obstruction and reducing weight loss in animal models of COPD. ${ }^{192}$

Palovarotene (C, an orally active, gamma-selective retinoid agonist has been studied in patients with emphysema secondary to alpha-1-proteinase inhibitor deficiency as a model population for smoke-induced emphysema. Early clinical trials showed beneficial effects in multiple functional lung parameters, ${ }^{193,194}$ but further development as a COPD treatment has recently been abandoned.

Ongoing Phase I clinical trials of patients with advanced pulmonary emphysema treated with autologous infusion of bone marrow mononuclear cells have shown promising results with improved spirometry, slowed progression of emphysema, and improved quality of life without significant adverse effects. ${ }^{195}$

\section{Conclusion}

The availability of increasing numbers of therapeutic agents brings new optimism in the management of patients with COPD. The short-action inhaled bronchodilators will continue to be necessary for the relief of intermittent symptoms, or as rescue medication in event of breakthrough symptoms. Short-acting muscarinic antagonists and short-acting beta agonists can be prescribed as metered-dose inhalers (hydrofluoroalkane) or as soft-mist inhaler formulations. Novel long-acting inhaled bronchodilators are suitable as maintenance (daily) treatment in patients with persistent symptoms who find the need to use any type of inhaler on a daily basis. The choice includes LAMA, LABA, or LAMALABA combination therapy. Patients with uncontrolled disease despite taking both LAMA and LABA should be referred for specialist evaluation in the hopes of identifying a specific COPD phenotype that might be suitable for additional pharmacotherapy. Such phenotypes might include the asthma-COPD overlap syndrome in which triple-inhaler therapy can be considered through the addition of an ICS. Frequent exacerbators, those with lower airway bacterial colonization and those with coexistent bronchiectasis, could be considered for oral treatment with a selective PDE4 inhibitor or long-term antibiotic prophylaxis. Future studies may reveal the necessity to recognize COPD as a disease with many manifestations requiring a specific and tailored therapeutic approach for each of its clinical phenotypes.

\section{Disclosure}

IZB has received research contracts from GlaxoSmithKline and participated in research studies sponsored by Spiration and Amgen. CBC has received research contracts from Amgen, Boehringer Ingelheim, GlaxoSmithKline, and Spiration; honoraria for lecturing from Astra-Zeneca, Boehringer Ingelheim, Forest, GlaxoSmithKline, and Sunovion; and consultant fees from Boehringer Ingelheim, eResearch Technology, Forest, GlaxoSmithKline, PulmonX, Spiration, and Sunovion. AFA reports no conflicts of interest in this work.

\section{References}

1. Vestbo J, Hurd SS, Agustí AG, et al. Global strategy for the diagnosis, management, and prevention of chronic obstructive pulmonary disease: GOLD executive summary. Am J Respir Crit Care Med. 2013;187(4): 347-365.

2. Siedlinski M, Tingley D, Lipman PJ, et al; COPDGene and ECLIPSE Investigators. Dissecting direct and indirect genetic effects on chronic obstructive pulmonary disease (COPD) susceptibility. Hum Genet. 2013; 132(4):431-441.

3. Schikowski T, Mills IC, Anderson HR, et al. Ambient air pollution: a cause of COPD? Eur Respir J. 2014;43(1):250-263.

4. Mannino DM, Buist AS. Global burden of COPD: risk factors, prevalence, and future trends. Lancet. 2007;370(9589):765-773.

5. Halbert RJ, Natoli JL, Gano A, Badamgarav E, Buist AS, Mannino DM. Global burden of COPD: systematic review and meta-analysis. Eur Respir J. 2006;28(3):523-532.

6. Lozano R, Naghavi M, Foreman K, et al. Global and regional mortality from 235 causes of death for 20 age groups in 1990 and 2010: a systematic analysis for the Global Burden of Disease Study 2010. Lancet. 2012;380(9859):2095-2128.

7. Guarascio AJ, Ray SM, Finch CK, Self TH. The clinical and economic burden of chronic obstructive pulmonary disease in the USA. Clinicoecon Outcomes Res. 2013;5:235-245.

8. Anthonisen NR, Connett JE, Murray RP. Smoking and lung function of Lung Health Study participants after 11 years. Am J Respir Crit Care Med. 2002;166(5):675-679.

9. Man WD, Polkey MI, Donaldson N, Gray BJ, Moxham J. Community pulmonary rehabilitation after hospitalisation for acute exacerbations of chronic obstructive pulmonary disease: randomised controlled study. BMJ. 2004;329(7476):1209.

10. Naunheim KS, Wood DE, Mohsenifar Z, et al; National Emphysema Treatment Trial Research Group. Long-term follow-up of patients receiving lung-volume-reduction surgery versus medical therapy for severe emphysema by the National Emphysema Treatment Trial Research Group. Ann Thorac Surg. 2006;82(2):431-443. 
11. Hosenpud JD, Bennett LE, Keck BM, Edwards EB, Novick RJ. Effect of diagnosis on survival benefit of lung transplantation for end-stage lung disease. Lancet. 1998;351(9095):24-27.

12. Cooper CB, Barjaktarevic, IZ. A new algorithm for the management of COPD. Lancet Respir Med. 2015;3(4):266-268.

13. Cooper CB, Tashkin DP. Recent developments in inhaled therapy in stable chronic obstructive pulmonary disease. BMJ. 2005;330(7492): 640-644.

14. Celli BR, MacNee W; ATS/ERS Task Force. Standards for the diagnosis and treatment of patients with COPD: a summary of the ATS/ ERS position paper. Eur Respir J. 2004;23(6):932-946.

15. BTS guidelines for the management of chronic obstructive pulmonary disease. The COPD Guidelines Group of the Standards of Care Committee of the BTS. Thorax. 1997;52 Suppl 5:S1-S28.

16. O’Donnell DE, Hernandez P, Kaplan A, et al. Canadian Thoracic Society recommendations for management of chronic obstructive pulmonary disease - 2008 update - highlights for primary care. Can Respir J. 2008;15 Suppl A:1A-8A.

17. Bateman ED, Hurd SS, Barnes PJ, et al. Global strategy for asthma management and prevention: GINA executive summary. Eur Respir J. 2008;31(1):143-178.

18. Chung KF, Wenzel SE, Brozek JL, et al. International ERS/ATS guidelines on definition, evaluation and treatment of severe asthma. Eur Respir J. 2014;43(2):343-373.

19. Celli BR, Barnes PJ. Exacerbations of chronic obstructive pulmonary disease. Eur Respir J. 2007;29(6):1224-1238.

20. Cooper CB, Celli BR, Jardim JR, et al. Treadmill endurance during 2-year treatment with tiotropium in patients with COPD: a randomized trial. Chest. 2013;144(2):490-497.

21. Casaburi R, Kukafka D, Cooper CB, Witek TJ Jr, Kesten S. Improvement in exercise tolerance with the combination of tiotropium and pulmonary rehabilitation in patients with COPD. Chest. 2005;127(3): 809-817.

22. Tashkin DP, Celli B, Senn S, et al; UPLIFT Study Investigators. A 4-year trial of tiotropium in chronic obstructive pulmonary disease. N Engl J Med. 2008;359(15):1543-1554.

23. Calverley P, Pauwels R, Vestbo J, et al; TRial of Inhaled STeroids ANd long-acting beta 2 agonists study group. Combined salmeterol and fluticasone in the treatment of chronic obstructive pulmonary disease: a randomised controlled trial. Lancet. 2003;361(9356):449-456.

24. Pauwels RA, Löfdahl CG, Laitinen LA, et al. Long-term treatment with inhaled budesonide in persons with mild chronic obstructive pulmonary disease who continue smoking. European Respiratory Society Study on Chronic Obstructive Pulmonary Disease. N Engl J Med. 1999; 340(25):1948-1953.

25. Vestbo J, Sørensen T, Lange P, Brix A, Torre P, Viskum K. Long-term effect of inhaled budesonide in mild and moderate chronic obstructive pulmonary disease: a randomised controlled trial. Lancet. 1999; 353(9167):1819-1823.

26. Lung Health Study Research Group. Effect of inhaled triamcinolone on the decline in pulmonary function in chronic obstructive pulmonary disease. N Engl J Med. 2000;343(26):1902-1909.

27. Szafranski W, Cukier A, Ramirez A, et al. Efficacy and safety of budesonide/formoterol in the management of chronic obstructive pulmonary disease. Eur Respir J. 2003;21(1):74-81.

28. Crim C, Calverley PM, Anderson JA, et al. Pneumonia risk in COPD patients receiving inhaled corticosteroids alone or in combination: TORCH study results. Eur Respir J. 2009;34(3):641-647.

29. Singh S, Amin AV, Loke YK. Long-term use of inhaled corticosteroids and the risk of pneumonia in chronic obstructive pulmonary disease: a meta-analysis. Arch Intern Med. 2009;169(3):219-229.

30. Novartis Pharmaceuticals. Study to Evaluate the Efficacy and Safety of Glycopyrronium or Indacaterol Maleate and Glycopyrronium Bromide Fixed-dose Combination Regarding Symptoms and Health Status in Patients With Moderate COPD Switching From Treatment With Any Standard COPD Regimen. Available from: https://clinicaltrials.gov/ ct2/show/NCT01985334. NLM identifier: NCT01985334. Accessed June 17, 2015.
31. GlaxoSmithKline. Safety, Tolerability, Pharmacokinetic and Pharmacodynamic Effects of GSK573719 (LAMA) and GW642444 (LABA) Administered Individually and Concurrently in Healthy Japanese Subjects (DB2113208). Available from: https://clinicaltrials.gov/ct2/ show/NCT00976144?term=NCT00976144\&rank=1. NLM identifier: NCT00976144. Accessed June 17, 2015.

32. GlaxoSmithKline. Pharmacokinetics Of Umeclidinium and Vilanterol in Healthy Chinese, a Randomized, Open Label, 3 Crossover Study. Available from: https://clinicaltrials.gov/ct2/show/NCT01899638?ter m=NCT01899638\&rank=1. NLM identifier: NCT01899638. Accessed June 17, 2015.

33. GlaxoSmithKline. A Study to Evaluate the Effect of Umeclidinium (UMEC) as Combination Therapy in Subjects With Chronic Obstructive Pulmonary Disease (COPD). Available from: https://clinicaltrials.gov/ ct2/show/NCT02257372?term=NCT02257372\&rank=1. NLM identifier: NCT02257372. Accessed June 17, 2015.

34. Jones PW, Singh D, Bateman ED, et al. Efficacy and safety of twicedaily aclidinium bromide in COPD patients: the ATTAIN study. Eur Respir J. 2012;40(4):830-836.

35. Kerwin EM, D’Urzo AD, Gelb AF, Lakkis H, Garcia Gil E, Caracta CF; ACCORD I study investigators. Efficacy and safety of a 12-week treatment with twice-daily aclidinium bromide in COPD patients (ACCORD COPD I). COPD. 2012;9(2):90-101.

36. Fuhr R, Magnussen H, Sarem K, et al. Efficacy of aclidinium bromide $400 \mu \mathrm{g}$ twice daily compared with placebo and tiotropium in patients with moderate to severe COPD. Chest. 2012;141(3): $745-752$.

37. Joos GF. Potential for long-acting muscarinic antagonists in chronic obstructive pulmonary disease. Expert Opin Investig Drugs. 2010;19(2): 257-264.

38. Rennard SI, Scanlon PD, Ferguson GT, et al. ACCORD COPD II: a randomized clinical trial to evaluate the 12 -week efficacy and safety of twice-daily aclidinium bromide in chronic obstructive pulmonary disease patients. Clin Drug Investig. 2013;33(12): 893-904.

39. Gelb AF, Tashkin DP, Make BJ, Zhong X, Garcia Gil E, Caracta C; LAS-MD-35 study investigators. Long-term safety and efficacy of twice-daily aclidinium bromide in patients with COPD. Respir Med. 2013;107(12):1957-1965

40. D’Urzo A, Kerwin E, Rennard S, He T, Garcia Gil E, Caracta C. Oneyear extension study of ACCORD COPD I: safety and efficacy of two doses of twice-daily aclidinium bromide in patients with COPD. COPD. 2013;10(4):500-510.

41. Jones PW, Rennard SI, Agusti A, et al. Efficacy and safety of oncedaily aclidinium in chronic obstructive pulmonary disease. Respir Res. 2011;12:55.

42. Chanez P, Burge PS, Dahl R, et al. Aclidinium bromide provides longacting bronchodilation in patients with COPD. Pulm Pharmacol Ther. 2010;23(1):15-21.

43. Kerwin E, Hébert J, Gallagher N, et al. Efficacy and safety of NVA237 versus placebo and tiotropium in patients with COPD: the GLOW2 study. Eur Respir J. 2012;40(5):1106-1114

44. D’Urzo A, Ferguson GT, van Noord JA, et al. Efficacy and safety of once-daily NVA237 in patients with moderate-to-severe COPD: the GLOW1 trial. Respir Res. 2011;12:156.

45. Verkindre C, Fukuchi Y, Flémale A, et al. Sustained 24-h efficacy of NVA237, a once-daily long-acting muscarinic antagonist, in COPD patients. Respir Med. 2010;104(10):1482-1489.

46. Vogelmeier C, Verkindre C, Cheung D, et al. Safety and tolerability of NVA237, a once-daily long-acting muscarinic antagonist, in COPD patients. Pulm Pharmacol Ther. 2010;23(5):438-444.

47. Ulrik CS. Once-daily glycopyrronium bromide, a long-acting muscarinic antagonist, for chronic obstructive pulmonary disease: a systematic review of clinical benefit. Int J Chron Obstruct Pulmon Dis. 2012;7:673-678. 
48. Tal-Singer R, Cahn A, Mehta R, et al. Initial assessment of single and repeat doses of inhaled umeclidinium in patients with chronic obstructive pulmonary disease: two randomised studies. Eur J Pharmacol. 2013;701(1-3):40-48.

49. Trivedi R, Richard N, Mehta R, Church A. Umeclidinium in patients with COPD: a randomised, placebo-controlled study. Eur Respir J. 2014; 43(1):72-81.

50. Feldman G, Walker RR, Brooks J, Mehta R, Crater G. 28-Day safety and tolerability of umeclidinium in combination with vilanterol in COPD: a randomized placebo-controlled trial. Pulm Pharmacol Ther. 2012;25(6):465-471.

51. Battram C, Charlton SJ, Cuenoud B, et al. In vitro and in vivo pharmacological characterization of 5-[(R)-2-(5,6-diethyl-indan-2-ylamino)1-hydroxy-ethyl]-8-hydroxy-1H-quinolin-2-one (indacaterol), a novel inhaled beta(2) adrenoceptor agonist with a 24-h duration of action. $J$ Pharmacol Exp Ther. 2006;317(2):762-770.

52. Mahler DA, D’Urzo A, Bateman ED, et al; INTRUST-1 and INTRUST-2 study investigators. Concurrent use of indacaterol plus tiotropium in patients with COPD provides superior bronchodilation compared with tiotropium alone: a randomised, double-blind comparison. Thorax. 2012;67(9):781-788.

53. Dahl R, Chung KF, Buhl R, et al; INVOLVE (INdacaterol: Value in COPD: Longer Term Validation of Efficacy and Safety) Study Investigators. Efficacy of a new once-daily long-acting inhaled beta2agonist indacaterol versus twice-daily formoterol in COPD. Thorax. 2010;65(6):473-479.

54. Kornmann O, Dahl R, Centanni S, et al; INLIGHT-2 (Indacaterol Efficacy Evaluation Using 150- $\mathrm{gg}$ Doses with COPD Patients) study investigators. Once-daily indacaterol versus twice-daily salmeterol for COPD: a placebo-controlled comparison. Eur Respir J. 2011;37(2):273-279.

55. Korn S, Kerwin E, Atis S, Amos C, Owen R, Lassen C; INSIST study group. Indacaterol once-daily provides superior efficacy to salmeterol twice-daily in COPD: a 12-week study. Respir Med. 2011; 105(5):719-726

56. Buhl R, Dunn LJ, Disdier C, et al; INTENSITY study investigators. Blinded 12-week comparison of once - daily indacaterol and tiotropium in COPD. Eur Respir J. 2011;38(4):797-803.

57. Chapman KR, Rennard SI, Dogra A, Owen R, Lassen C, Kramer B; INDORSE Study Investigators. Long-term safety and efficacy of indacaterol, a long-acting $\beta_{2}$-agonist, in subjects with COPD: a randomized, placebo-controlled study. Chest. 2011;140(1):68-75.

58. O'Donnell DE, Casaburi R, Vincken W, et al; INABLE 1 study group. Effect of indacaterol on exercise endurance and lung hyperinflation in COPD. Respir Med. 2011;105(7):1030-1036.

59. Decramer M, Rossi A, Lawrence D, McBryan D. Indacaterol therapy in patients with COPD not receiving other maintenance treatment. Respir Med. 2012;106(12):1706-1714.

60. Donohue JF, Singh D, Kornmann O, Lawrence D, Lassen C, Kramer B. Safety of indacaterol in the treatment of patients with COPD. Int $J$ Chron Obstruct Pulmon Dis. 2011;6:477-492.

61. Khindri S, Sabo R, Harris S, Woessner R, Jennings S, Drollmann AF. Cardiac safety of indacaterol in healthy subjects: a randomized, multidose, placebo- and positive-controlled, parallel-group thorough QT study. BMC Pulm Med. 2011;11:31.

62. Chowdhury BA, Seymour SM, Michele TM, Durmowicz AG, Liu D, Rosebraugh CJ. The risks and benefits of indacaterol - the FDA's review. N Engl J Med. 2011;365(24):2247-2249.

63. Hanania NA, Feldman G, Zachgo W, et al. The efficacy and safety of the novel long-acting $\beta 2$ agonist vilanterol in patients with COPD: a randomized placebo-controlled trial. Chest. 2012;142(1):119-127.

64. Lötvall J, Bateman ED, Bleecker ER, et al. 24-h duration of the novel LABA vilanterol trifenatate in asthma patients treated with inhaled corticosteroids. Eur Respir J. 2012;40(3):570-579.

65. Slack RJ, Barrett VJ, Morrison VS, et al. In vitro pharmacological characterization of vilanterol, a novel long-acting $\beta 2$-adrenoceptor agonist with 24-hour duration of action. J Pharmacol Exp Ther. 2013; 344(1):218-230.
66. McKeage K. Fluticasone furoate/vilanterol: a review of its use in chronic obstructive pulmonary disease. Drugs. 2014;74(13):1509-1522.

67. Cazzola M, Page CP, Rogliani P, Matera MG. $\beta 2$-agonist therapy in lung disease. Am J Respir Crit Care Med. 2013;187(7):690-696.

68. Pepin JL, Cockcroft JR, Midwinter D, Sharma S, Rubin DB, Andreas S. Long-acting bronchodilators and arterial stiffness in patients with COPD: a comparison of fluticasone furoate/vilanterol with tiotropium. Chest. 2014;146(6):1521-1530.

69. Celli B, Crater G, Kilbride S, et al. Once-daily umeclidinium/vilanterol 125/25 mcg in COPD: a randomized, controlled study. Chest. Epub 2014 Jan 2.

70. Decramer M, Anzueto A, Kerwin E, et al. Efficacy and safety of umeclidinium plus vilanterol versus tiotropium, vilanterol, or umeclidinium monotherapies over 24 weeks in patients with chronic obstructive pulmonary disease: results from two multicentre, blinded, randomised controlled trials. Lancet Respir Med. 2014;2(6):472-486.

71. Dransfield MT, Bourbeau J, Jones PW, et al. Once-daily inhaled fluticasone furoate and vilanterol versus vilanterol only for prevention of exacerbations of COPD: two replicate double-blind, parallelgroup, randomised controlled trials. Lancet Respir Med. 2013;1(3): 210-223.

72. US Food and Drug Administration. FDA approves Anoro Ellipta to treat chronic obstructive pulmonary disease [press release]. Silver Spring, MD: US Food and Drug Administration; 2013 [Dec 18]. Available from: http://www.fda.gov/newsevents/newsroom/pressannouncements/ ucm379057.htm. Accessed June 17, 2015.

73. van Noord JA, Smeets JJ, Drenth BM, et al. 24-hour bronchodilation following a single dose of the novel $\beta(2)$-agonist olodaterol in COPD. Pulm Pharmacol Ther. 2011;24(6):666-672.

74. Cazzola M, Calzetta L, Matera MG. $\beta(2)$-adrenoceptor agonists: current and future direction. Br J Pharmacol. 2011;163(1):4-17.

75. O’Byrne PM, van der Linde J, Cockcroft DW, et al. Prolonged bronchoprotection against inhaled methacholine by inhaled BI 1744, a long-acting beta(2)-agonist, in patients with mild asthma. J Allergy Clin Immunol. 2009;124(6):1217-1221.

76. Koch A, Pizzichini E, Hamilton A, et al. Lung function efficacy and symptomatic benefit of olodaterol once daily delivered via Respimat ${ }^{\mathbb{R}}$ versus placebo and formoterol twice daily in patients with GOLD 2-4 COPD: results from two replicate 48-week studies. Int J Chron Obstruct Pulmon Dis. 2014;9:697-714.

77. Profita M, Albano GD, Riccobono L, et al. Increased levels of Th17 cells are associated with non-neuronal acetylcholine in COPD patients. Immunobiology. 2014;219(5):392-401.

78. Ferguson GT, Feldman GJ, Hofbauer P, et al. Efficacy and safety of olodaterol once daily delivered via Respimat ${ }^{\mathbb{R}}$ in patients with GOLD 2-4 COPD: results from two replicate 48-week studies. Int J Chron Obstruct Pulmon Dis. 2014;9:629-645.

79. Timmer W, Massana E, Jimenez E, Seoane B, de Miquel G, Ruiz S. First-in-human study of the safety, tolerability, pharmacokinetics and pharmacodynamics of abediterol (LAS100977), a novel long-acting B2-agonist. J Clin Pharmacol. 2014;54(12):1347-1353.

80. Cazzola M, Rogliani P, Segreti A, Matera MG. An update on bronchodilators in Phase I and II clinical trials. Expert Opin Investig Drugs. 2012;21(10):1489-1501.

81. Broadley KJ. Beta-adrenoceptor responses of the airways: for better or worse? Eur J Pharmacol. 2006;533(1-3):15-27.

82. Kempsford R, Norris V, Siederer S. Vilanterol trifenatate, a novel inhaled long-acting beta2 adrenoceptor agonist, is well tolerated in healthy subjects and demonstrates prolonged bronchodilation in subjects with asthma and COPD. Pulm Pharmacol Ther. 2013;26(2): 256-264.

83. Tashkin DP, Ferguson GT. Combination bronchodilator therapy in the management of chronic obstructive pulmonary disease. Respir Res. 2013;14:49.

84. Cazzola M, Centanni S, Santus P, et al. The functional impact of adding salmeterol and tiotropium in patients with stable COPD. Respir Med. 2004;98(12):1214-1221. 
85. Cazzola M, Segreti A, Matera MG. New developments in the combination treatment of COPD: focus on umeclidinium/vilanterol. Drug Des Devel Ther. 2013;7:1201-1208.

86. Kelly E. Umeclidinium bromide and vilanterol in combination for the treatment of chronic obstructive pulmonary disease. Expert Rev Clin Pharmacol. 2014;7(4):403-413.

87. Donohue JF, Niewoehner D, Brooks J, O’Dell D, Church A. Safety and tolerability of once-daily umeclidinium/vilanterol 125/25 mcg and umeclidinium $125 \mathrm{mcg}$ in patients with chronic obstructive pulmonary disease: results from a 52-week, randomized, double-blind, placebocontrolled study. Respir Res. 2014;15:78.

88. Kelleher D, Tombs L, Preece A, Brealey N, Mehta R. A randomized, placebo- and moxifloxacin-controlled thorough QT study of umeclidinium monotherapy and umeclidinium/vilanterol combination in healthy subjects. Pulm Pharmacol Ther. 2014;29(1):49-57.

89. Rodrigo GJ, Plaza V. Efficacy and safety of a fixed-dose combination of indacaterol and Glycopyrronium for the treatment of COPD: a systematic review. Chest. 2014;146(2):309-317.

90. Vincken W, Aumann J, Chen H, Henley M, McBryan D, Goyal P. Efficacy and safety of coadministration of once-daily indacaterol and glycopyrronium versus indacaterol alone in COPD patients: the GLOW6 study. Int J Chron Obstruct Pulmon Dis. 2014;9:215-228.

91. Bateman ED, Ferguson GT, Barnes N, et al. Dual bronchodilation with QVA149 versus single bronchodilator therapy: the SHINE study. Eur Respir J. 2013;42(6):1484-1494.

92. Rodrigo GJ, Plaza V. Efficacy and safety of indacaterol and Glycopyrronium in COPD: an update. Chest. 2014;146(2):e75.

93. Cazzola M, Rogliani P, Matera MG. Aclidinium bromide/formoterol fumarate fixed-dose combination for the treatment of chronic obstructive pulmonary disease. Expert Opin Pharmacother. 203;14(6):755-781.

94. Pearl Therapeutics, Inc. Study to Assess the Efficacy and Safety of PT003, PT005, and PT001 in Subjects With Moderate to Very Severe COPD. Available from: https://clinicaltrials.gov/ct2/show/NCT02343 458?term=NCT02343458\&rank=1. NLM identifier: NCT02343458. Accessed June 11, 2015.

95. Pearl Therapeutics, Inc. Crossover Study to Assess the Efficacy of PT003 With and Without a Valved Holding Chamber in Subjects With Moderate to Severe COPD. Available from: https://clinicaltrials. gov/ct2/show/NCT02454959?term=NCT02454959\&rank=1. NLM identifier: NCT02454959. Accessed June 11, 2015.

96. Pearl Therapeutics, Inc. 24-hour Lung Function in Subjects With Moderate to Very Severe COPD After Treatment With PT003 and Placebo MDI. Available from: https://clinicaltrials.gov/ct2/show/NCT02347 085?term=NCT02347085\&rank=1. NLM identifier: NCT02347085. Accessed June 11, 2015.

97. Pearl Therapeutics, Inc. 24-hour Lung Function in Subjects With Moderate to Very Severe COPD After Treatment With PT003, Open-Label Spiriva ${ }^{\circledR}$ Respimat ${ }^{\circledR}$ as an Active Control, and Placebo. Available from: https://clinicaltrials.gov/ct2/show/NCT02347072?term=NCT0234707 2\&rank=1. NLM identifier: NCT02347072. Accessed June 11, 2015.

98. Pearl Therapeutics, Inc. 24-hour Lung Function in Subjects With Moderate to Very Severe COPD After Treatment With PT003, OpenLabel Spiriva ${ }^{\mathbb{R}}$ Respimat $^{\mathbb{E}}$ as an Active Control, and Placebo. Available from: https:/clinicaltrials.gov/ct2/show/NCT02347072?term=NCT02 347072\&rank=1. NLM identifier: NCT02347072. Accessed June 11, 2015.

99. Pearl Therapeutics, Inc. Glycopyrronium and Formoterol Fumarate (GFF) Metered Dose Inhaler (MDI) Dose Indicator Study in Adults With Moderate to Very Severe COPD. Available from: https://clinicaltrials.gov/ct2/show/NCT02268396?term=NCT02268396\&rank= 1. NLM identifier: NCT02268396. Accessed June 11, 2015.

100. Reisner C, Fogarty C, Spangenthal S, Dunn L, Kerwin EM, Quinn D. Novel combination of glycopyrrolate and formoterol MDI (GFF-MDI) provides superior bronchodilation compared to its components administered alone, tiotropium DPI, and formoterol DPI in a randomized, double-blind, placebo-controlled phase $2 \mathrm{~b}$ study in patients with COPD [abstract]. Am J Respir Crit Care Med. 2011;183:A6453.
101. Reisner C, St Rose E, Strom S, et al. Fixed combination of glycopyrrolate and formoterol MDI (GFF-MDI) demonstrates superior inspiratory capacity (IC) compared to tiotropium DPI (Tio) following 7 days dosing, in a randomized, double-blind, placebo-controlled phase 2b study in patients with COPD [abstract P879]. Eur Respir J. 2011;38(Suppl 55):150s.

102. Tamm M, Richards DH, Beghé B, Fabbri L. Inhaled corticosteroid and long-acting $\beta 2$-agonist pharmacological profiles: effective asthma therapy in practice. Respir Med. 2012;106 Suppl 1:S9-S19.

103. Nelson HS, Chapman KR, Pyke SD, Johnson M, Pritchard JN. Enhanced synergy between fluticasone propionate and salmeterol inhaled from a single inhaler versus separate inhalers. J Allergy Clin Immunol. 2003;112(1):29-36.

104. Kew KM, Dias S, Cates CJ. Long-acting inhaled therapy (betaagonists, anticholinergics and steroids) for COPD: a network metaanalysis. Cochrane Database Syst Rev. 2014;3:CD010844.

105. Dong YH, Lin HH, Shau WY, Wu YC, Chang CH, Lai MS. Comparative safety of inhaled medications in patients with chronic obstructive pulmonary disease: systematic review and mixed treatment comparison metaanalysis of randomised controlled trials. Thorax. 2013;68(1):48-56.

106. US Food and Drug Administration. Novel New Drugs 2013 Summary. Silver Spring, MD: US Food and Drug Administration; 2014. Available from: http:/www.fda.gov/downloads/drugs/developmentapprovalprocess/druginnovation/ucm381803.pdf. Accessed June 17, 2015.

107. Dransfield MT, Feldman G, Korenblat P, et al. Efficacy and safety of once-daily fluticasone furoate/vilanterol $(100 / 25 \mathrm{mcg})$ versus twice-daily fluticasone propionate/salmeterol $(250 / 50 \mathrm{mcg})$ in COPD patients. Respir Med. 2014;108(8):1171-1179.

108. Cazzola M, Matera MG. Emerging inhaled bronchodilators: an update. Eur Respir J. 2009;34(3):757-769.

109. Fuhr R, Vaidya S, Khindri S, et al. Pharmacokinetics (PK) of indacaterol acetate and mometasone furoate delivered alone or in combination following once daily inhalation in healthy subjects. Eur Respir J. 2014;44(Suppl 58):P903

110. Beasley RW, Donohue JF, Mehta R, et al. Effect of once-daily indacaterol maleate/mometasone furoate on exacerbation risk in adolescent and adult asthma: a double-blind randomised controlled trial. $B M J$ Open. 2015;5(2):e006131.

111. Korn S, Buhl R. Efficacy of a fixed combination of ciclesonide and formoterol: the EXCITED-study. Respir Med. 2012;106(1):57-67.

112. Papi A, Blasi F, Canonica GW, et al. Fluticasone propionate/formoterol: A fixed-combination therapy with flexible dosage. Eur J Intern Med. 2014;25(8):695-700.

113. McKeage K. Fluticasone propionate/formoterol fumarate: a review of its use in persistent asthma. Drugs. 2013;73(2):195-206.

114. Karner C, Cates CJ. Long-acting beta(2)-agonist in addition to tiotropium versus either tiotropium or long-acting beta(2)-agonist alone for chronic obstructive pulmonary disease. Cochrane Database Syst Rev. 2012;4:CD008989.

115. Karner C, Cates CJ. The effect of adding inhaled corticosteroids to tiotropium and long-acting beta(2)-agonists for chronic obstructive pulmonary disease. Cochrane Database Syst Rev. 2011CD009039.

116. Short PM, Williamson PA, Elder DH, Lipworth SI, Schembri S, Lipworth BJ. The impact of tiotropium on mortality and exacerbations when added to inhaled corticosteroids and long-acting $\beta$-agonist therapy in COPD. Chest. 2012;141(1):81-86.

117. Lee TA, Wilke C, Joo M, et al. Outcomes associated with tiotropium use in patients with chronic obstructive pulmonary disease. Arch Intern Med. 2009;169(15):1403-1410.

118. Hanania NA, Crater GD, Morris AN, Emmett AH, O’Dell DM, Niewoehner DE. Benefits of adding fluticasone propionate/salmeterol to tiotropium in moderate to severe COPD. Respir Med. 2012;106(1):91-101.

119. Welte T, Miravitlles M, Hernandez P, et al. Efficacy and tolerability of budesonide/formoterol added to tiotropium in patients with chronic obstructive pulmonary disease. Am J Respir Crit Care Med. 2009; 180(8):741-750. 
120. Chatterjee A, Shah M, D'Souza AO, Bechtel B, Crater G, Dalal AA. Observational study on the impact of initiating tiotropium alone versus tiotropium with fluticasone propionate/salmeterol combination therapy on outcomes and costs in chronic obstructive pulmonary disease. Respir Res. 2012;13:15.

121. Jung KS, Park HY, Park SY, et al; Korean Academy of Tuberculosis and Respiratory Diseases study group; Korea Chronic Obstructive Pulmonary Disease study group. Comparison of tiotropium plus fluticasone propionate/salmeterol with tiotropium in COPD: a randomized controlled study. Respir Med. 2012;106(3):382-389.

122. Aaron SD, Vandemheen KL, Fergusson D, et al; Canadian Thoracic Society/Canadian Respiratory Clinical Research Consortium. Tiotropium in combination with placebo, salmeterol, or fluticasonesalmeterol for treatment of chronic obstructive pulmonary disease: a randomized trial. Ann Intern Med. 2007;146(8):545-555.

123. Hughes $\mathrm{AD}$, Jones LH. Dual-pharmacology muscarinic antagonist and $\beta 2$ agonist molecules for the treatment of chronic obstructive pulmonary disease. Future Med Chem. 2011;3(13):1585-1605.

124. Sturton G, Fitzgerald M. Phosphodiesterase 4 inhibitors for the treatment of COPD. Chest. 2002;121(5 Suppl):192S-196S.

125. Barnes PJ. Emerging pharmacotherapies for COPD. Chest. 2008;134(6): 1278-1286.

126. Page CP, Spina D. Selective PDE inhibitors as novel treatments for respiratory diseases. Curr Opin Pharmacol. 2012;12(3):275-286.

127. Rennard S, Knobil K, Rabe KF, et al. The efficacy and safety of cilomilast in COPD. Drugs. 2008;68 Suppl 2:3-57.

128. Pinner NA, Hamilton LA, Hughes A. Roflumilast: a phosphodiesterase-4 inhibitor for the treatment of severe chronic obstructive pulmonary disease. Clin Ther. 2012;34(1):56-66.

129. RabeKF, BatemanED, O’DonnellD, Witte S, BredenbrökerD, BethkeTD. Roflumilast - an oral anti-inflammatory treatment for chronic obstructive pulmonary disease: a randomised controlled trial. Lancet. 2005;366(9485):563-571.

130. Calverley PM, Rabe KF, Goehring UM, Kristiansen S, Fabbri LM, Martinez FJ; M2-124 and M2-125 study groups. Roflumilast in symptomatic chronic obstructive pulmonary disease: two randomised clinical trials. Lancet. 2009;374(9691):685-694.

131. Fabbri LM, Calverley PM, Izquierdo-Alonso JL, et al; M2-127 and M2-128 study groups. Roflumilast in moderate-to-severe chronic obstructive pulmonary disease treated with longacting bronchodilators: two randomised clinical trials. Lancet. 2009;374(9691):695-703.

132. Baye J. Roflumilast (daliresp): a novel phosphodiesterase-4 inhibitor for the treatment of severe chronic obstructive pulmonary disease. P T. 2012;37(3):149-161.

133. Gupta S. Side-effects of roflumilast. Lancet. 2012;379(9817):710-711; author reply 711-712.

134. Monsó E, Ruiz J, Rosell A, et al. Bacterial infection in chronic obstructive pulmonary disease. A study of stable and exacerbated outpatients using the protected specimen brush. Am J Respir Crit Care Med. 1995;152(4 Pt 1):1316-1320.

135. Soler N, Torres A, Ewig S, et al. Bronchial microbial patterns in severe exacerbations of chronic obstructive pulmonary disease (COPD) requiring mechanical ventilation. Am J Respir Crit Care Med. 1998;157(5 Pt 1):1498-1505.

136. Pela R, Marchesani F, Agostinelli C, et al. Airways microbial flora in COPD patients in stable clinical conditions and during exacerbations: a bronchoscopic investigation. Monaldi Arch Chest Dis. 1998; 53(3):262-267.

137. Anthonisen NR, Manfreda J, Warren CP, Hershfield ES, Harding GK, Nelson NA. Antibiotic therapy in exacerbations of chronic obstructive pulmonary disease. Ann Intern Med. 1987;106(2):196-204.

138. Wenzel RP, Fowler AA 3rd, Edmond MB. Antibiotic prevention of acute exacerbations of COPD. N Engl J Med. 2012;367(4):340-347.

139. Pomares X, Montón C, Espasa M, Casabon J, Monsó E, Gallego M. Long-term azithromycin therapy in patients with severe COPD and repeated exacerbations. Int J Chron Obstruct Pulmon Dis. 2011;6:449-456.
140. Ramos FL, Criner GJ. Use of long-term macrolide therapy in chronic obstructive pulmonary disease. Curr Opin Pulm Med. 2014;20(2): 153-158.

141. Uzun S, Djamin RS, Kluytmans JA, et al. Azithromycin maintenance treatment in patients with frequent exacerbations of chronic obstructive pulmonary disease (COLUMBUS): a randomised, double-blind, placebo-controlled trial. Lancet Respir Med. 2014;2(5): 361-368.

142. Berkhof FF, Doornewaard-ten Hertog NE, Uil SM, Kerstjens HA, van den Berg JW. Azithromycin and cough-specific health status in patients with chronic obstructive pulmonary disease and chronic cough: a randomised controlled trial. Respir Res. 2013;14:125.

143. Albert RK, Connett J, Bailey WC, et al; COPD Clinical Research Network. Azithromycin for prevention of exacerbations of COPD. $N$ Engl J Med. 2011;365(8):689-698.

144. Han MK, Tayob N, Murray S, et al. Predictors of chronic obstructive pulmonary disease exacerbation reduction in response to daily azithromycin therapy. Am J Respir Crit Care Med. 2014;189(12):1503-1508.

145. Ray WA, Murray KT, Hall K, Arbogast PG, Stein CM. Azithromycin and the risk of cardiovascular death. $N$ Engl J Med. 2012;366(20): 1881-1890.

146. Peters J, Anzueto A. Azithromycin once daily for 1 year reduced acute COPD exacerbations. Ann Intern Med. 2012;156(2):JC1-J10.

147. Chapman SJ. Antibiotic prevention of acute exacerbations of COPD. N Engl J Med. 2012;367(19):1866; author reply 1867.

148. Garcia-Vidal C, Viasus D, Carratalà J. Antibiotic prevention of acute exacerbations of COPD. $N$ Engl J Med. 2012;367(19):1866; author reply 1867.

149. Schwarz DG. Antibiotic prevention of acute exacerbations of COPD. N Engl J Med. 2012;367(19):1865; author reply 1867.

150. Siegel D. Antibiotic prevention of acute exacerbations of COPD. $N$ Engl J Med.2012;367(19):1865; author reply 1867.

151. Zaidi N, Nawab Q. Antibiotic prevention of acute exacerbations of COPD. N Engl J Med. 2012;367(19):1864-1865; author reply 1867.

152. DiNicolantonio JJ. Azithromycin for prevention of exacerbations of COPD. N Engl J Med. 2011;365(23):2235; author reply 2236.

153. Hahn DL. Azithromycin for prevention of exacerbations of COPD. N Engl J Med. 2011;365(23):2236-2236; author reply 2236-2237.

154. Sethi S, Jones PW, Theron MS, et al; PULSE Study group. Pulsed moxifloxacin for the prevention of exacerbations of chronic obstructive pulmonary disease: a randomized controlled trial. Respir Res. 2010;11:10

155. Criner GJ, Connett JE, Aaron SD, et al; COPD Clinical Research Network; Canadian Institutes of Health Research. Simvastatin for the prevention of exacerbations in moderate-to-severe COPD. $N$ Engl $J$ Med. 2014;370(23):2201-2210.

156. Moretto N, Caruso P, Bosco R, et al. CHF6001 I: a novel highly potent and selective phosphodiesterase 4 inhibitor with robust antiinflammatory activity and suitable for topical pulmonary administration. J Pharmacol Exp Ther. 2015;352(3):559-567.

157. Franciosi LG, Diamant Z, Banner KH, et al. Efficacy and safety of RPL554, a dual PDE3 and PDE4 inhibitor, in healthy volunteers and in patients with asthma or chronic obstructive pulmonary disease: findings from four clinical trials. Lancet Respir Med. 2013;1(9):714-727.

158. Matera MG, Page C, Cazzola M. PDE inhibitors currently in early clinical trials for the treatment of asthma. Expert Opin Investig Drugs. 2014;23(9):1267-1275.

159. Kobayashi Y, Wada H, Rossios C, et al. A novel macrolide solithromycin exerts superior anti-inflammatory effect via NF- $\kappa B$ inhibition. J Pharmacol Exp Ther. 2013;345(1):76-84.

160. Davis SS, Scobie S, Inglis A. The effect of sulphydryl compounds and cross linking agents on the viscous and viscoelastic properties of mucus. Biorheology. 1975;12(3-4):225-232.

161. Sadowska AM. N-Acetylcysteine mucolysis in the management of chronic obstructive pulmonary disease. Ther Adv Respir Dis. 2012;6(3):127-135. 
162. Sheffner AL. The reduction in vitro in viscosity of mucoprotein solutions by a new mucolytic agent, N-acetyl-L-cysteine. Ann N Y Acad Sci. 1963;106:298-310.

163. Mata M, Ruiz A, Cerda M, et al. Oral N-acetylcysteine reduces bleomycin-induced lung damage and mucin Muc5ac expression in rats. Eur Respir J. 2003;22(6):900-905.

164. Shen Y, Cai W, Lei S, Zhang Z. Effect of high/low dose N-acetylcysteine on chronic obstructive pulmonary disease: a systematic review and meta-analysis. COPD. 2014;11(3):351-358.

165. Cazzola M, Matera MG. N-acetylcysteine in COPD may be beneficial, but for whom? Lancet Respir Med. 2014;2(3):166-167.

166. Zheng JP, Wen FQ, Bai CX, et al; PANTHEON study group. Twice daily $\mathrm{N}$-acetylcysteine $600 \mathrm{mg}$ for exacerbations of chronic obstructive pulmonary disease (PANTHEON): a randomised double-blind placebo-controlled trial. Lancet Respir Med. 2014;2(3): 187-194.

167. Turner RD, Bothamley GH. N-acetylcysteine for COPD: the evidence remains inconclusive. Lancet Respir Med. 2014;2(4):e3.

168. Rennard SI, Dale DC, Donohue JF, et al. CXCR2 Antagonist MK-7123. A phase 2 proof-of-concept trial for chronic obstructive pulmonary disease. Am J Respir Crit Care Med. 2015;191(9): 1001-1011.

169. Khorasani N, Baker J, Johnson M, Chung KF, Bhavsar PK. Reversal of corticosteroid insensitivity by $\mathrm{p} 38$ MAPK inhibition in peripheral blood mononuclear cells from COPD. Int J Chron Obstruct Pulmon Dis. 2015;10:283-291.

170. MacNee W, Allan RJ, Jones I, De Salvo MC, Tan LF. Efficacy and safety of the oral p38 inhibitor PH-797804 in chronic obstructive pulmonary disease: a randomised clinical trial. Thorax. 2013;68(8): 738-745.

171. Pfizer. Study To Evaluate The Efficacy And Safety Of PH-797804 For 12 Weeks In Adults With Moderate To Severe Chronic Obstructive Pulmonary Disease (COPD) On A Background Of Tiotropium Bromide. Available from: https://clinicaltrials.gov/ct2/show/ NCT01543919. NLM identifier: NCT01543919. Accessed June 11, 2015.

172. Watz H, Barnacle H, Hartley BF, Chan R. Efficacy and safety of the p38 MAPK inhibitor losmapimod for patients with chronic obstructive pulmonary disease: a randomised, double-blind, placebo-controlled trial. Lancet Respir Med. 2014;2(1):63-72.

173. Norman P. Investigational p38 inhibitors for the treatment of chronic obstructive pulmonary disease. Expert Opin Investig Drugs. 2015;24(3): 383-392.

174. Kodgule R, Vaidya A, Salvi S. Newer therapies for chronic obstructive pulmona disease. J Assoc Physicians India. 2012;60 Suppl:8-13.

175. Churg A, Wang R, Wang X, Onnervik PO, Thim K, Wright JL. Effect of an MMP-9/MMP-12 inhibitor on smoke-induced emphysema and airway remodelling in guinea pigs. Thorax. 2007;62(8): 706-713.

176. Caramori G, Adcock IM, Di Stefano A, Chung KF. Cytokine inhibition in the treatment of COPD. Int J Chron Obstruct Pulmon Dis. 2014;9:397-412.

177. AstraZeneca. Efficacy and Safety Study of Benralizumab in Adults and Adolescents Inadequately Controlled on Inhaled Corticosteroid Plus Long-acting $\beta 2$ Agonist. Available from: https://clinicaltrials. gov/ct2/show/NCT01914757?term=NCT01914757\&rank=1. NLM identifier: NCT01914757. Accessed June 11, 2015.

178. AstraZeneca. Study to Evaluate the Efficacy and Safety of Benralizumab in Adult Patients With Mild to Moderate Persistent Asthma Available from: https:/clinicaltrials.gov/ct2/show/NCT02322775?ter $\mathrm{m}=$ NCT02322775\&rank=1. NLM identifier: NCT02322775. Accessed June 11, 2015.

179. AstraZeneca. Benralizumab Efficacy in Moderate to Very Severe Chronic Obstructive Pulmonary Disease (COPD) With Exacerbation History (GALATHEA). Available from: https:/clinicaltrials.gov/ct2/ show/NCT02138916?term=NCT02138916\&rank=1. NLM identifier: NCT02138916. Accessed June 11, 2015.
180. AstraZeneca. Efficacy and Safety Study of Benralizumab to Reduce OCS Use in Patients With Uncontrolled Asthma on High Dose Inhaled Corticosteroid Plus LABA and Chronic OCS Therapy. Available from: https:/clinicaltrials.gov/ct2/show/NCT02075255?term=NCT0207525 5\&rank=1. NLM identifier: NCT02075255. Accessed June 11, 2015.

181. AstraZeneca. Efficacy and Safety Study of Benralizumab Added to High-dose Inhaled Corticosteroid Plus LABA in Patients With Uncontrolled Asthma. Available from: https://clinicaltrials.gov/ct2/ show/NCT01928771?term=NCT01928771\&rank=1. NLM identifier: NCT01928771. Accessed June 11, 2015.

182. GlaxoSmithKline. A Phase 3a, Repeat Dose, Open-label, Long-term Safety Study of Mepolizumab in Asthmatic Subjects. Available from: https:/clinicaltrials.gov/ct2/show/NCT02135692?term=NCT0213569 2\&rank=1. NLM identifier: NCT02135692. Accessed June 11, 2015.

183. GlaxoSmithKline. Mepolizumab Steroid-Sparing Study in Subjects With Severe Refractory Asthma. Available from: https://clinicaltrials. gov/ct2/show/NCT01691508?term=NCT01691508\&rank=1. NLM identifier: NCT01691508. Accessed June 11, 2015.

184. GlaxoSmithKline. A Study to Determine Long-term Safety of Mepolizumab in Asthmatic Subjects. Available from: https:/clinicaltrials. gov/ct2/show/NCT01842607?term=NCT01842607\&rank=1. NLM identifier: NCT01842607. Accessed June 11, 2015.

185. McMaster University. Mepolizumab in Chronic Obstructive Pulmonary Diseases (COPD) With Eosinophilic Bronchitis. Available from: https:/clinicaltrials.gov/ct2/show/NCT01463644?term=NCT0146364 4\&rank=1. NLM identifier: NCT01463644. Accessed June 11, 2015.

186. GlaxoSmithKline. Efficacy and Safety of Mepolizumab as an Add-on Treatment in Chronic Obstructive Pulmonary Disease (COPD). Available from: https://clinicaltrials.gov/ct2/show/NCT02105961?term=NC T02105961\&rank=1. NLM identifier: NCT02105961. Accessed June 11,2015

187. GlaxoSmithKline. Efficacy and Safety Study of Mepolizumab Adjunctive Therapy in Participants With Severe Eosinophilic Asthma on Markers of Asthma Control. Available from: https://clinicaltrials. gov/ct2/show/NCT02281318?term=NCT02281318\&rank=1. NLM identifier: NCT02281318. Accessed June 11, 2015.

188. GlaxoSmithKline. Study to Evaluate Efficacy and Safety of Mepolizumab for Frequently Exacerbating Chronic Obstructive Pulmonary Disease (COPD) Patients. Available from: https:/clinicaltrials.gov/ ct2/show/NCT02105948?term=NCT02105948\&rank=1. NLM identifier: NCT02105948. Accessed June 11, 2015.

189. Brightling CE, Bleecker ER, Panettieri RA Jr, et al. Benralizumab for chronic obstructive pulmonary disease and sputum eosinophilia: a randomised, double-blind, placebo-controlled, phase 2a study. Lancet Respir Med. 2014;2(11):891-901.

190. Busse WW, Holgate S, Kerwin E, et al. Randomized, double-blind, placebo-controlled study of brodalumab, a human anti-IL-17 receptor monoclonal antibody, in moderate to severe asthma. Am J Respir Crit Care Med. 2013;188(11):1294-1302.

191. Sriskantharajah S, Hamblin N, Worsley S, Calver AR, Hessel EM, Amour A. Targeting phosphoinositide 3-kinase $\delta$ for the treatment of respiratory diseases. Ann N Y Acad Sci. 2013;1280:35-39.

192. Wang L, Yang J, Guo L, et al. Use of a soluble epoxide hydrolase inhibitor in smoke-induced chronic obstructive pulmonary disease Am J Respir Cell Mol Biol. 2012;46(5):614-622.

193. Stolk J, Stockley RA, Stoel BC, et al. Randomised controlled trial for emphysema with a selective agonist of the $\gamma$-type retinoic acid receptor. Eur Respir J. 2012;40(2):306-312.

194. Stolk J, Cooper BG, Stoel B, et al. Retinoid treatment of Emphysema in Patients on the Alpha-1 International Registry. The REPAIR study: study design, methodology and quality control of study assessments. Ther Adv Respir Dis. 2010;4(6):319-332.

195. Stessuk T, Ruiz MA, Greco OT, Bilaqui A, Ribeiro-Paes MJ, RibeiroPaes JT. Phase I clinical trial of cell therapy in patients with advanced chronic obstructive pulmonary disease: follow-up of up to 3 years. Rev Bras Hematol Hemoter. 2013;35(5):352-357. 
International Journal of COPD

Dovepress

\section{Publish your work in this journal}

The International Journal of COPD is an international, peer-reviewed journal of therapeutics and pharmacology focusing on concise rapid reporting of clinical studies and reviews in COPD. Special focus is given to the pathophysiological processes underlying the disease, intervention programs, patient focused education, and self management protocols.

This journal is indexed on PubMed Central, MedLine and CAS. The manuscript management system is completely online and includes a very quick and fair peer-review system, which is all easy to use. Visit http://www.dovepress.com/testimonials.php to read real quotes from published authors.

Submit your manuscript here: http://www.dovepress.com/international-journal-of-chronic-obstructive-pulmonary-disease-journal 